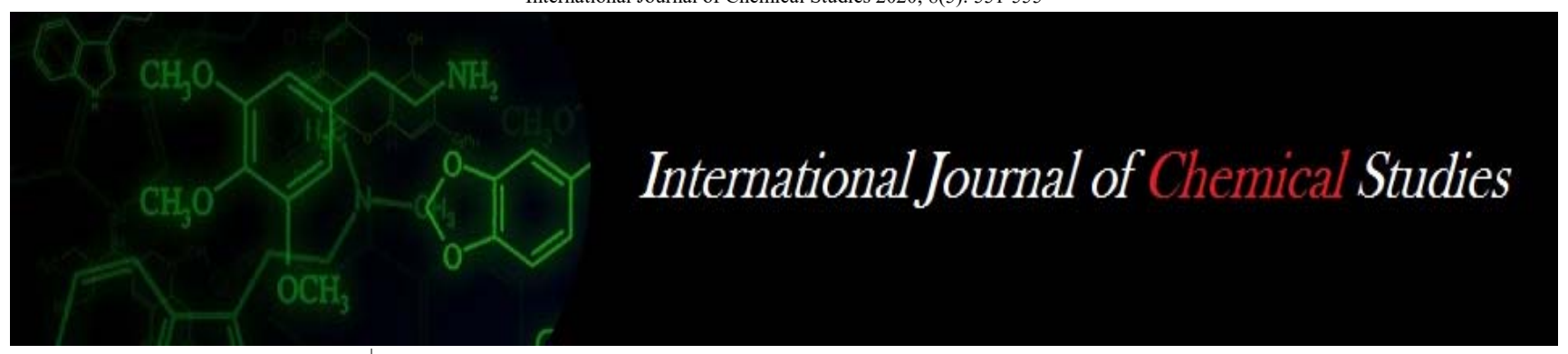

P-ISSN: 2349-8528 E-ISSN: 2321-4902 www.chemijournal.com IJCS 2020; 8(5): 551-555 (C) 2020 IJCS

Received: 12-07-2020 Accepted: 14-08-2020

\section{R Tejaswi}

Department of Floriculture and

Landscape Architecture,

Dr. Y.S.R.H.U., COH,

Venkataramannagudem

West Godavari District,

Andhra Pradesh, India

\section{Zehra Salma}

Department of Floriculture and Landscape Architecture, Dr. Y.S.R.H.U., COH

Venkataramannagudem, West Godavari District, Andhra Pradesh, India

\section{G Aditya}

Department of Floriculture and Landscape Architecture, Dr. Y.S.R.H.U., COH, Venkataramannagudem, West Godavari District, Andhra Pradesh, India
Corresponding Author: R Tejaswi

Department of Floriculture and

Landscape Architecture,

Dr. Y.S.R.H.U., COH,

Venkataramannagudem,

West Godavari District,

Andhra Pradesh, India

\section{Genotypic evaluation of crossandra (Crossandra infundibuliformis L.) under coastal region conditions of Andhra Pradesh}

\author{
R Tejaswi, Zehra Salma and G Aditya
}

DOI: $\underline{\text { https://doi.org/10.22271/chemi.2020.v8.i5h.10353 }}$

\begin{abstract}
The present research work was carried out during the year 2017-18 at College of Horticulture, Dr. Y.S.R Horticultural University, Venkataramannagudem, West Godavari district of Andhra Pradesh. The experiment consisted of 10 crossandra genotypes, laid out in randomized block design with three replications under open conditions. The observations were recorded on various parameters in which the genotype Arka Shravya exhibited superiority in parameters like plant spread $\left(1407.53 \mathrm{~cm}^{2}\right)$, number of leaves (241.24), Fresh weight of plant $(80.83 \mathrm{~g})$, Dry weight of plant $(20.21 \mathrm{~g})$, flowering duration of spike (26.33 days), rachis length $(12.77 \mathrm{~cm})$ and flower yield per sq. meter (1448.01) whereas, Arka kanaka showed the more spike length $(20.90 \mathrm{~cm})$ and longevity of flowers on plants 4.33 days while, Arka Shreeya found to be largest in flower size $(8.87 \mathrm{~cm})$ as compared to check and other genotypes.
\end{abstract}

Keywords: Crossandra, evaluation, genotypes, vegetative and quality

\section{Introduction}

Flowers are inseparable from the social fabric of human life. Flowers being an adorable creation of God, befits all occasions. Crossandra (Crossandra infundibuliformis L.) is commonly known as 'Fire cracker plant'. The word 'crossandra' was derived from Greek word 'Krossos' meaning 'a fringe' and 'aner' meaning 'a man', the anthers being fringed. All species of crossandra are native of the Arabian Peninsula, tropical Africa, Madagascar, India and Sri Lanka (Brickell, 1996) ${ }^{[2]}$. Being an important commercial flower, it is mainly grown in India, tropical Africa and Madagascar (Bailey, 1963) ${ }^{[1]}$. It has gained Royal Horticultural Society's Award of Garden Merit.

Crossandra is an evergreen shrub belonging to the family Acanthaceae. Its chromosome number is $2 n=40$. In India, loose flowers were grown in an area of 3.09 lakh hectares with a production of 16.53 lakh metric tons whereas, in Andhra Pradesh loose flowers were grown in an area of 16.59 thousand hectares with 140.34 thousand metric tons (NHB, 2017) ${ }^{[10]}$. Crossandra is cultivated in an area of 2,307 hectares with a production of 5,587 tonnes in Andhra Pradesh (DES, 2016) ${ }^{[3]}$.

The crop is a major commercial flower in South India and commercially grown in Karnataka, Tamil Nadu and Andhra Pradesh. Though the flowers are not fragrant like jasmine, rose or tuberose, they are priced high for their attractive colour and longer shelf life. The flowers are offered to temple deities and mostly used in making garlands, gajras and venis. It is sturdy, productive ornamental shrub suitable for temples and as garden landscape, grown in beds, borders and potted plants.

Crossandra consists of five coloured forms namely orange, yellow, red, deep orange and bluish flowered forms. The orange type is only variety commercially grown. But it is highly susceptible to wilt, root knot and lesion nematodes (Vadivelu and Muthukrishnan, 1980) ${ }^{[17]}$. Three other forms of crossandra are Yellow, Deep Orange and Sebacules Red are grown to a small extent (Velusamy et al., 1974) ${ }^{[18]}$. Deep orange red is triploid, similar to Mona Wallhead, the only cultivar of crossandra grown commercially in Denmark (Ottosen and Christensen, 1986) ${ }^{[11]}$. In India there are several genotypes under crossandra, including the IIHR varieties namely, Arka Ambara (IIHR 2004-9), Arka Kanaka (IIHR 2004-11), Arka Shreeya (Local x Arka Ambara) and Arka Shravya (Crossandra nilotica x Mangalore local). 
The price of crossandra increases at the peak time of occasions but, the cultivation and research on this crop is deficit. However, the performance of a genotype also varies and is greatly influenced by agro-climatic conditions like temperature, rainfall, soil etc. Thus, the performance of a genotype differs from region to region. Therefore, evaluation of available genotypes will help in identifying the best performing genotypes in a particular region. Further, it is also useful in crop improvement programmes to bring in new colours, forms with good keeping quality and biotic stress resistant varieties in this crop.

\section{Material and Methods}

The present study was carried out during the year 2017 to 2018 at College of Horticulture, Dr. Y.S.R Horticultural University, Venkataramannagudem, West Godavari District, Andhra Pradesh. The location falls under Agro-climatic zone10, humid, East Coast Plain and Hills (Krishna-Godavari zone) with an average annual rainfall of $900 \mathrm{~mm}$ at an altitude of $34 \mathrm{~m}$ (112 feet) above mean sea level. It experiences hot humid summer and mild winter.

The rooted cuttings of ten genotypes of crossandra were procured from ICAR-IIHR, Bengaluru, Karnataka, TNAU, Coimbatore, Tamil Nadu, HRS, Anantharajupeta and Kadiyam, Andhra Pradesh and planted in plots of $2.9 \mathrm{~m} \times 2.9$ $\mathrm{m}$ size at a spacing of $45 \mathrm{~cm} \times 45 \mathrm{~cm}$. Well decomposed farm yard manure at the rate of $25 \mathrm{t} \mathrm{FYM} \mathrm{and} \mathrm{the} \mathrm{recommended}$ dose of fertilizers viz., Urea, Single Super Phosphate and Muriate of Potash in a ratio of 50: 100: $60 \mathrm{~kg}$ per hectare were taken as the sources of $\mathrm{N}, \mathrm{P}_{2} \mathrm{O}_{5}$ and $\mathrm{K}_{2} \mathrm{O}$, respectively. Entire dose of phosphorus and potassium was given as basal application and the nitrogen was applied in two splits at 30 and 60 days after planting. The standard cultural practices were followed throughout the experiment and five plants were selected at random and tagged in each replication of respective treatments for the purpose of recording various observations on vegetative, flowering and yield parameters.

\section{Results and Discussion \\ Plant spread $\left(\mathrm{cm}^{2}\right)$}

Significant differences were observed among different genotypes of crossandra with respect to plant spread. At 150 DAP, the maximum plant spread was recorded in genotype Arka Shravya $\left(1407.53 \mathrm{~cm}^{2}\right)$. However, the genotype ACS-6 showed minimum plant spread $\left(674.30 \mathrm{~cm}^{2}\right)$. The maximum plant spread was exhibited by the genotype Arka Shravya $\left(1407.53 \mathrm{~cm}^{2}\right)$ as compared to the check $\left(1093.60 \mathrm{~cm}^{2}\right)$. Similar results were reported by Priyanka et al. (2017) ${ }^{[12]}$ in the genotype Arka Shravya. This may be due to peculiar branching and flowering habit of the plant producing spikes only on one side of the branch and also it has shown more internodal length and wider crotch angle between the branches. The differences in plant spread is a varietal trait and is probably governed by the genetic makeup. Varietal differences in plant spread was reported by Kulkarni and Reddy (2006) ${ }^{[7]}$ in China aster.

\section{Number of leaves}

Number of leaves per plant in different genotypes of crossandra exhibited the increased mean performance from 9.66 (30 DAP) to 143.64 (150 DAP). The genotype Arka Shravya showed significantly maximum number of leaves (241.24) which was followed by Arka Shreeya (156.21) whereas, the minimum number of leaves were recorded in ACS-6 (77.61) at 150 DAP. With respect to number of leaves per plant, the genotypes Arka Shravya (241.24) was found significantly superior than check (131.52) at 150 DAP.

\section{Fresh weight of the plant (g)}

The genotype Arka Shravya recorded maximum fresh weight of the plant $(80.83 \mathrm{~g})$ which was followed by Arka Kanaka $(61.83 \mathrm{~g})$. However, minimum fresh weight was observed in ACS-6 (51.33 g) at 150 DAP. The genotypes Arka Shravya (80.83 g) and Arka Kanaka (61.83 g) exhibited highest fresh weight of the plant than check (54.83 g) at 150 DAP. Kumar and Polara (2017) ${ }^{[8]}$ stated that fresh weight of different genotypes varies due to their genetical composition. Maximum fresh weight of plant observed might be due to highest plant height, plant spread, leaf area of respective genotypes which in turn would have facilitated more photosynthates to plant.

\section{Dry weight of the plant (g)}

Maximum dry weight of the plant was exhibited by Arka Shravya (20.21 g) which was followed by Arka Kanaka (15.46 g) whereas, the genotype ACS-6 showed minimum (12.84 g) dry weight of the plant. Among different genotypes of crossandra, the genotypes Arka Shravya (20.21 g) and Arka Kanaka (15.46 g) showed highest dry weight of the plant as compared to check (13.72 g) at 150 DAP. Dry weight of the plant depicts that how efficiently the plant has absorbed the water and minerals and used them to produce the biomass with assimilation (Shafique et al., 2011) ${ }^{[16]}$. It may also depend on genotypic characters of different varieties.

\section{Flowering duration of spike (days)}

The comparison among genotypes revealed that Arka Shravya showed longer flowering duration (26.33 days) while, Arka Ambara (10.00) and ACS-6 (8.00) showed less duration of flowering than check (13.00) whereas, all the remaining genotypes observed to be on par with it. The longer rachis length and maximum number of florets on spike in Arka Shravya might have been contributed for longer flowering duration of spike.

\section{Interval between floret opening in a spike (days)}

The results taken from Table 1 showed no significant variations related to interval between floret opening in a spike among different genotypes of crossandra studied.

\section{Rachis length (cm)}

There was a significant difference in the rachis length of different crossandra genotypes (Table 2). The longest rachis length was observed in genotype Arka Shravya $(12.77 \mathrm{~cm})$ and was significantly superior to all other genotypes which were on par among each other. However, ACS-6 $(6.83 \mathrm{~cm})$ recorded minimum rachis length. The longest rachis length was found in the genotype Arka Shravya $(12.77 \mathrm{~cm})$ as compared to check $(8.13 \mathrm{~cm})$. The superiority in vegetative characters like plant height, number of leaves and leaf area in Arka Shravya might have resulted in supply of more photosynthates to the spike thereby showing superior floral characters. The differences in spike length and rachis length can be attributed to the genetic constitution of the hybrids (Kishan, 2010 and Naresh et al., 2015) ${ }^{[6,9]}$ in gladiolus.

\section{Spike length (cm)}

The genotypes of crossandra studied were compared among themselves with respect to spike length $(\mathrm{cm})$ ranging from $8.00 \mathrm{~cm}$ to $20.90 \mathrm{~cm}$ as furnished in Table 2. The longest 
spike length was recorded in genotype Arka Kanaka (20.90 $\mathrm{cm})$ which was found to be on par with Arka Shravya (19.10 $\mathrm{cm})$, Nilakottai Local $(17.60 \mathrm{~cm})$, Kadiyam Local 2 (17.60 $\mathrm{cm})$, Arka Ambara $(17.30 \mathrm{~cm})$ and Bengaluru Local $(17.07$ $\mathrm{cm})$. However, the genotype ACS-6 recorded minimum rachis length $(8.00 \mathrm{~cm})$. The variation in spike length of different genotypes might be due their genotypic character. Ramachandralu and Thangam (2009) ${ }^{[13]}$, Dimri et al. (2017) ${ }^{[4]}$ in Tuberose, Rani et al. (2007) ${ }^{[15]}$ in gladiolus. Shafique et al. (2011) ${ }^{[16]}$ reported that the difference in flower spike length is not only influenced by their genetic makeup but Local environmental conditions during production time and soil nutrition also play a vital role on the growth and development of Snapdragon cultivars

\section{Flower yield per square meter $(\mathrm{g})$}

The genotype Arka Shravya recorded significantly maximum flower yield per square meter (1448.01 g) which was followed by Arka Kanaka (627.52 g). However, the minimum flower yield was observed in ACS-6 (94.04 g). The higher yield might be due to increased morphological parameters which help in production of more photosynthates resulting in greater accumulation of dry matter which in turn leads to production of more number of flowers per plant. The results are in line with the findings of Priyanka et al. (2017) ${ }^{[12]}$ and Ramachandrudu and Thangam (2010) ${ }^{[14]}$ in crossandra and Joshi et al. (2009) ${ }^{[5]}$ in chrysanthemum.

\section{Floret colour}

The colour of flowers in crossandra is an important feature since the consumer preference is dependent on the colour. (Ramachandrudu and Thangam, 2010) ${ }^{[14]}$ and is presented in Table 2. Wide variation among floret colour was observed among different genotypes is represented in Plate 1.

Varied floret colours like Tangerine Orange colour with bright Yellow center (Arka Ambara, Nilakottai Local and Bengaluru Local, respectively), Yellowish Orange with
Yellow center (Arka Kanaka), Apricot Orange with Yellow center (Arka Shreeya), Fire Orange with Yellow center having reddish tinge in the periphery (Arka Shravya), Carrot Orange with Yellow center (Kadiyam Local 1), Orange Yellow colour with green center (Kadiyam Local 2), Bluish green colour with white center (ACS-6) and Honey Orange colour with light yellow center (Ratan aboli) were observed in different crossandra genotypes. The variation in floret colour among different crossandra genotypes may be attributed to genetic constitution of the genotypes.

\section{Floret size $\left(\mathrm{cm}^{2}\right)$}

Perusal of data ranging from $3.17 \mathrm{~cm}^{2}$ to $8.87 \mathrm{~cm}^{2}$ presented in Table 2, there was significant variations with respect to floret size of different crossandra genotypes. The maximum floret size was observed in the genotype Arka Shreeya (8.87 $\mathrm{cm}^{2}$ ) which was on par with genotype Arka Ambara (8.14 $\mathrm{cm}^{2}$ ). However, the genotype Nilakottai Local recorded minimum floret size $\left(3.17 \mathrm{~cm}^{2}\right)$. The variation in floret size might be due to the genetic makeup of the varieties and the prevailing conditions during the field trial. It was also advocated by Dimri et al. (2017) ${ }^{[4]}$ in tuberose.

\section{In situ longevity of floret (days)}

The data pertaining to in situ longevity of floret showed significant variations among genotypes studied ranging from 1.41 days to 2.31 days which was presented in the Table 2 . The genotype Arka Kanaka recorded more days of in situ longevity (2.31 days) among different genotypes which was on par with Arka Ambara (2.23 days) and Arka Shreeya (2.23 days). Whereas, minimum days of in situ longevity was recorded in genotype ACS-6 (1.41 days). The differences in In-situ longevity of floret among different genotypes of crossandra might be due to variation in compactness of calyx, spike character and moisture retentivity of spike and florets across the genotypes.

Table 1: Vegetative and flowering parameters in ten genotypes of crossandra

\begin{tabular}{|c|c|c|c|c|c|c|c|}
\hline $\begin{array}{c}\text { S. } \\
\text { No. }\end{array}$ & Treatments & $\begin{array}{c}\text { Plant spread } \\
\left(\mathrm{cm}^{2}\right)\end{array}$ & \begin{tabular}{|c|}
$\begin{array}{c}\text { Number of } \\
\text { leaves per plant }\end{array}$ \\
\end{tabular} & \begin{tabular}{|c|}
$\begin{array}{c}\text { Fresh weight of } \\
\text { the plant }(\mathrm{g})\end{array}$ \\
\end{tabular} & \begin{tabular}{|c|} 
Dry weight of \\
the plant (g)
\end{tabular} & \begin{tabular}{|c|}
$\begin{array}{c}\text { Flowering duration } \\
\text { of spike (days) }\end{array}$ \\
\end{tabular} & \begin{tabular}{|c} 
Interval between \\
floret opening (days)
\end{tabular} \\
\hline 1. & Arka Ambara & 1122.33 & 154.75 & 55.83 & 13.98 & 10.00 & $1.00(1.41)$ \\
\hline 2. & Arka Kanaka & 1152.10 & 153.03 & 61.83 & 15.46 & 13.33 & $1.13(1.46)$ \\
\hline 3. & Arka Shreeya & 1039.53 & 156.21 & 57.50 & 14.39 & 14.33 & $1.00(1.41)$ \\
\hline 4. & Arka Shravya & 1407.53 & 241.24 & 80.83 & 20.21 & 26.33 & $1.00(1.41)$ \\
\hline 5. & Nilakottai Local & 1000.57 & 106.49 & 54.67 & 13.67 & 15.67 & $1.00(1.41)$ \\
\hline 6. & Bengaluru Local & 997.65 & 142.06 & 52.45 & 13.12 & 11.67 & $1.07(1.44)$ \\
\hline 7. & Ratanaboli & 1047.93 & 148.97 & 57.35 & 14.35 & 11.33 & $1.00(1.41)$ \\
\hline 8. & Kadiyam Local 2 & 1020.20 & 124.56 & 56.28 & 14.08 & 11.00 & $1.00(1.41)$ \\
\hline 9. & $\mathrm{ACS}-6$ & 674.30 & 77.61 & 51.33 & 12.84 & 8.00 & $1.00(1.41)$ \\
\hline 10. & Kadiyam Local 1 (check) & 1093.60 & 131.52 & 54.83 & 13.72 & 13.00 & $1.00(1.41)$ \\
\hline & Mean & 1055.57 & 143.64 & 58.29 & 14.58 & 13.67 & $1.02(1.42)$ \\
\hline & $\mathrm{SEm} \pm$ & 75.45 & 11.59 & 2.11 & 0.53 & 1.00 & 1.00 \\
\hline & $\mathrm{CD}$ at $\overline{5 \%}$ & 225.92 & 34.69 & 6.32 & 1.58 & 2.99 & $\mathrm{~N} / \mathrm{S}$ \\
\hline
\end{tabular}

* The values in brackets are square root transformed values 
Table 2: Yield and quality parameters in ten genotypes of crossandra

\begin{tabular}{|c|c|c|c|c|c|c|c|}
\hline $\begin{array}{l}\text { S. } \\
\text { No. }\end{array}$ & Treatments & $\begin{array}{c}\text { Rachis length } \\
\text { (cm) }\end{array}$ & \begin{tabular}{|c|}
$\begin{array}{c}\text { Spike length } \\
\text { (cm) }\end{array}$ \\
\end{tabular} & \begin{tabular}{|l|} 
Flower yield per \\
square meter (g)
\end{tabular} & Floret colour & $\begin{array}{c}\text { Floret size } \\
\left(\mathrm{cm}^{2}\right)\end{array}$ & $\begin{array}{c}\text { In situ Longevity of } \\
\text { floret (days) }\end{array}$ \\
\hline 1. & Arka Ambara & 7.97 & 17.30 & 420.81 & Tangerine Orange & 8.14 & $4.00(2.23)$ \\
\hline 2. & Arka Kanaka & 9.13 & 20.90 & 627.52 & Yellowish Orange & 6.36 & $4.33(2.31)$ \\
\hline 3. & Arka Shreeya & 7.50 & 15.17 & 498.13 & Apricot Orange & 8.87 & $4.00(2.23)$ \\
\hline 4. & Arka Shravya & 12.77 & 19.10 & 1448.01 & Fire Orange & 6.67 & $3.67(2.16)$ \\
\hline 5. & Nilakottai Local & 8.70 & 17.60 & 378.61 & Tangerine Orange & 3.17 & $2.67(1.91)$ \\
\hline 6. & Bengaluru Local & 7.33 & 17.07 & 488.40 & Tangerine Orange & 4.72 & $3.33(2.08)$ \\
\hline 7. & Ratanaboli & 7.73 & 13.90 & 306.16 & Honey Orange & 4.12 & $2.33(1.82)$ \\
\hline 8. & Kadiyam Local 2 & 8.53 & 17.60 & 195.88 & Orange Yellow & 5.07 & $2.33(1.82)$ \\
\hline 9. & $\mathrm{ACS}-6$ & 6.83 & 8.00 & 94.04 & Bluish green & 4.35 & $1.00(1.41)$ \\
\hline 10. & Kadiyam Local 1 (check) & 8.13 & 15.40 & 266.87 & Carrot Orange & 3.43 & $2.67(1.91)$ \\
\hline & Mean & 8.46 & 16.20 & 472.44 & & 5.49 & $3.03(1.99)$ \\
\hline & SEm + & 0.57 & 1.52 & 79.02 & & 0.52 & 0.08 \\
\hline & $\mathrm{CD}$ at $\overline{5 \%}$ & 1.69 & 4.54 & 26.39 & & 1.54 & 0.23 \\
\hline
\end{tabular}

* The values in brackets are square root transformed values

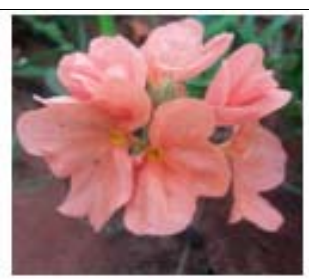

Arka Ambara

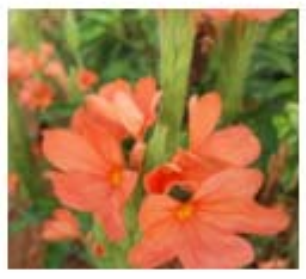

Arka Shravya

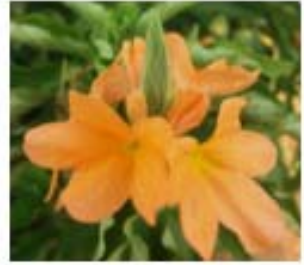

Ratan aboli

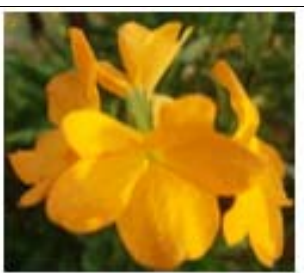

Arka Kanaka

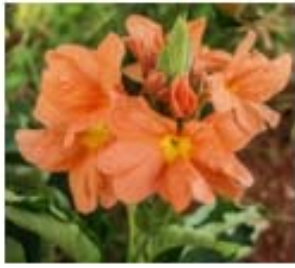

Nilakottai Local

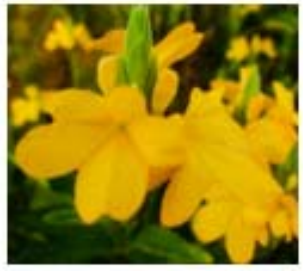

Kadiyam Local 2

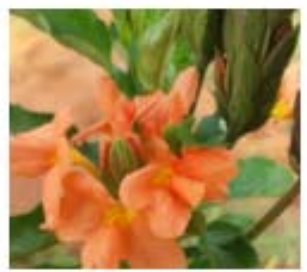

Kadivam Local 1 (check)

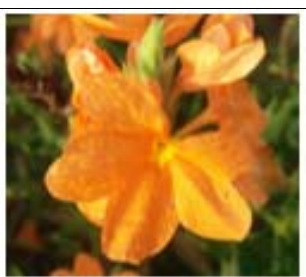

Arka Shreeya

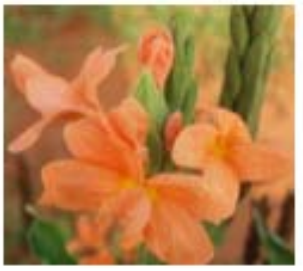

Bengaluru Local

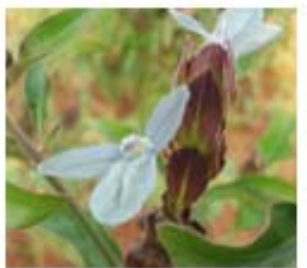

ACS-6

Plate 1: Crossandra genotypes studied

\section{Acknowledgement}

This paper forms the part of thesis of the first author in the Dept. of Floriculture \& Landscape Architecture submitted to the Dr. YSR Horticultural University,
Venkataramannagudem, Andhra Pradesh, India. The author wants to thank HRS (Dr. YSRHU), Anantharajupeta, IIHR, Bengaluru and TNAU, Coimbatore for supply of the planting material for the research work. 


\section{References}

1. Bailey L. The Standard Cyclopedia of Horticulture. New York, U.S.A.: The Macmillan Company, 1963.

2. Brickell. A-Z Encyclopedia of Garden Plant, Dorling Kindersley, London, 1996, 319.

3. DES. District wise area, yield and production of crossandra 2015-16. Directorate of Economics and Statistics Government of Andhra Pradesh. http://www.desap.cgg.gov.in. 2016.

4. Dimri S, Punetha P, Bohra M, Tanuja. Screening of suitable germplasm of tuberose (Polianthes tuberose L.) For mid hill conditions of Garhwal Himalayas. International Journal of Agricultural Science and Research. 2017; 7(2):499-506.

5. Joshi Manoj, Varma LR, Masu MM. Performance of different varieties of chrysanthemum in respect of growth, flowering and flower yield under north Gujarat condition. The Asian Journal of Horticulture. 2009; 4(2):292-94

6. Kishan S. Morphological variation and evaluation of gladiolus germplasm. Indian Journal of Agricultural Sciences. 2010; 80(8):742-745.

7. Kulkarni BS, Reddy BS. Vegetative growth and flower yield as influenced by different cultivars of China aster. Haryana Journal of Horticultural Sciences. 2006; 35(3/4):269-70.

8. Kumar AS, Polara ND. Evaluation of Chrysanthemum Varieties on Growth and Quality under South Saurashtra Region. International Journal of Pure \& Applied Bioscience 2017; 5(4):1989-97.

9. Naresh S, Dorajeerao AVD, Bhaskar VV, Umakrishna K, Paratpararao M. Evaluation of gladiolus (Gladiolus hybrid L.) hybrids under coastal Andhra Pradesh. Plant Archives. 2015; 15(1):451-54.

10. NHB. State wise area and production of loose flowers. Horticultural Statistics at a Glance 2016-17, National Horticulture Board, Ministry of Agriculture and Farmers welfare, Government of India, Gurgon. New Delhi. http://www.nhb.gov.in. 2017, 222-223.

11. Ottosen CO, Christensen OU. Gartenbauwissenchaft. 1986; 51(4):156-159.

12. Priyanka TK, Kamble BS, Anuradha RW, Kumar N, Shirol AM. Evaluation of different crossandra genotypes under ghataprabha command area. Journal of Pharmacognosy and Phytochemistry. 2017; 6(6):252-254.

13. Ramachandrudu K, Thangam M. Performance of tuberose (Polianthes tuberosa L.) cultivars in Goa. Journal of Horticulture Science. 2009; 4(1):76-77.

14. Ramachandrudu K, Thangam M. Characterization and evaluation of local Germplasm of crossandra (Crossandra undulaefolia Salisb.). Journal of Ornamental Horticulture. 2010; 13(2):138-141.

15. Rani R, Prasad KK, Ranjan R. Study on varietal performance in gladiolus. Orissa Journal of Horticulture. 2007; 35(2):35-38.

16. Shafique A, Maqbool M, Nawaz MA, Ahmed W. Performance of various snapdragon (Antirrhinum majus L.) Cultivars as cut flower in Punjab, Pakistan. Pakistan Journal of Botany. 2011; 43(2):1003-1010.

17. Vadivelu S, Muthukrishnan TS. National seminar on Production Technology ofcommercial Flower crops. Coimbatore, India. Tamil Nadu Agricultural University, 1980.

18. Velusamy P, Thangaraj T, Muthuswamy S. South Indian Horticulture. 1974; 22:81-83. 